\title{
PENGARUH MOTIVASI KERJA DAN KEPUASAN KERJA TERHADAP KINERJA KARYAWAN
}

\author{
Gilang Arnaldo dan Kurniati W. Andani \\ Program Studi Manajemen Fakultas Ekonomi Universitas Tarumanagara, Jakarta \\ gilangarnaldo.ga@gmail.com
}

\begin{abstract}
The purpose of this research is to examine the effect of work motivation and job satisfaction on employee performance at PT. Togo Steel Industries Tangerang. The data were collected using questionnaire. In total 85 respondents, then the data were analyzed by SmartPLS software. The result of this study indicate that work motivation and job satisfaction had positive effects on employee performance.
\end{abstract}

Keywords: Work Motivation, Job Satisfaction, Employee Performance.

Abstrak: Tujuan dari penelitian ini adalah untuk menguji pengaruh dari motivasi kerja dan kepuasan kerja terhadap kinerja karyawan. Data dikumpulkan dengan menggunakan kuesioner. Totalnya, terkumpul sebanyak 85 responden, kemudian data dianalisis menggunakan software SmartPLS. Hasil dari penelitian ini menunjukkan bahwa motivasi kerja dan kepuasan kerja berpengaruh positif terhadap kinerja karyawan.

Kata Kunci : Motivasi Kerja, Kepuasan Kerja, Kinerja Karyawan.

\section{LATAR BELAKANG}

PT. Togo Steel Industries adalah perusahaan yang bergerak di bidang industri yang memproduksi kawat dan baja. Produk yang dihasilkan seperti Wiremesh, Baja Ringan, Bondeck, dan Kolom Praktis. Seiring dengan berjalannya waktu, dimana Indonesia telah beberapa kali mengalami krisis,

PT. Togo Steel Industries hadir dengan berbekal pengalaman di industri pabrik baja dan di industri Wiremesh, kiranya dapat selalu memenuhi kehendak pasar yang terus berkembang. PT. Togo Steel Industries dilengkapi mesin - mesin dilengkapi dengan sistem komputerisasi dan perkembangan teknologi saat ini.

Pada dasarnya, sumber daya manusia merupakan sumber daya yang sangat dibutuhkan oleh suatu organisasi atau perusahaan. Sebab, sumber daya manusia merupakan sumber daya yang terlibat langsung dalam kegiatan suatu organisasi atau perusahaan dan juga dalam proses pengambilan keputusan. Hasil pengambilan suatu keputusan terbaik dihasilkan oleh sumber daya manusia yang memiliki kinerja terbaik dan kemampuan dalam menganalisis suatu masalah dalam ruang lingkup kerja dan jabatannya.

Suatu organisasi atau perusahaan dikatakan telah mencapai tujuannya apabila sumber saya manusia yang dimiliki menghasilkan kinerja yang sesuai dengan target atau visi yang telah ditentukan. Oleh karena itu, kinerja karyawan dalam suatu organisasi atau perusahaan menjadi sangat penting. Kinerja atau hasil kerja yang baik tidak terlepas dari peran seorang pemimpin yang baik juga. Sehingga pemimpin harus mampu menghasilkan kondisi yang 
dapat mendorong atau mendukung karyawan untuk mengembangkan dan meningkatkan kemampuan serta keterampilan yang dimiliki secara efisien.

Upaya yang bisa ditempuh perusahaan diantaranya adalah dengan memotivasi karyawan dengan berbagai cara untuk menghasilkan kinerja yang maksimal sehingga karyawan dapat mencapai kepuasan kerja. Pada umumnya, karyawan yang memiliki kepuasan kerja akan lebih setia dan meningkatkan kinerjanya terhadap perusahaan.

Motivasi kerja menurut Reksohadiprodjo \& Handoko (2001) merupakan keadaan dalam pribadi seseorang yang mendorong keinginan individu untuk melakukan kegiatan tertentu guna mencapai tujuan. Hal tersebut dapat diartikan bahwa motivasi kerja yang ada pada seseorang akan menciptakan suatu tindakan yang diarahkan pada tujuan mencapai sasaran yang sudah ditentukan.

Selain motivasi kerja, perusahaan juga harus memperhatikan tentang kepuasan kerja, karena jika karyawan yang bekerja tidak merasakan kenyamanan dan kurang diperhatikan, akan cenderung sulit untuk mengembangkan atau memaksimalkan potensi yang dimiliki, maka secara langsung karyawan tidak dapat mengerjakan tugas yang diberikan secara fokus dan konsentrasi. Karyawan yang memiliki kepuasan kerja yang tinggi tentu juga memiliki semangat kerja yang tinggi, sehingga prestasi kerja yang dihasilkan akan maksimal pula.

Kepuasan kerja karyawan menurut Hariandja (2002) mendefinisikan jika pekerjaan tidak hanya sekedar melakukan pekerjaan, tetapi terkait juga dengan aspek lain seperti melakukan interaksi dengan rekan kerja, atasan, mengikuti aturan-aturan dan lingkungan kerja tertentu yang seringkali tidak memadai atau kurang disukai.

\section{KAJIAN TEORI}

\section{Motivasi Kerja}

Motivasi berasal dari motive atau bahasa latinnya, yaitu movere, yang berarti "mengerahkan". Motivasi merupakan kebutuhan, keinginan, dorongan atau rangsangan bagi setiap individu dalam suatu organisasi. Praktik motivasi yang positif dapat meningkatkan produktivitas dan kualitas kerja karyawan. Motivasi kerja dapat ditinjau dari dorongan yang diberikan oleh perusahaan untuk meningkatkan kerja dari karyawan itu sendiri sehingga dapat menciptakan hasil kerja yang baik.

Adapun beberapa pendapat yang dikemukakan oleh para ahli tentang motivasi kerja, diataranya adalah pendapat dari Torang (2016) yang mendefinisikan motivasi kerja sebagai energi yang menggerakan individu untuk berusaha mencapai tujuan yang diharapkan dalam melakukan pekerjaannya. Menurut Anoraga (2014), motivasi kerja adalah sesuatu yang menimbulkan semangat atau dorongan kerja. Sedangkan menurut Bangun (2012), motivasi kerja berarti kondisi yang mendorong atau menjadi sebab seseorang melakukan suatu pekerjaan atau kegiatan, yang berlangsung secara sadar.

Berdasarkan uraian diatas maka dapat disimpulkan bahwa seseorang yang termotivasi, adalah orang yang melakukan pekerjaan atau tugas yang diberikan dengan sangat bergairah, untuk mencapai tujuan-tujuan yang telah ditetapkan oleh departemen, dan organisasi dimana ia bekerja. Menurut (Saputra \& Andani, 2021) dengan adanya motivasi dalam diri pegawai tentunya akan membuat mereka bekerja dengan serius, tekun, bergairah dan memiliki semangat kerja yang tinggi, ini akan berpengaruh terhadap hasil kerja. Hasil kerja yang baik akan mempengaruhi tingkat kepuasan kerja. 


\section{Kepuasan Kerja}

Kepuasan kerja merupakan suatu kondisi yang menggambarkan tingkat kepuasan seseorang terhadap pekerjaan yang ia lakukan karena sesuai dengan kemampuan dan harapan atau menerima pengharggaan dari hasil kerja yang dilakukan. Ketidakpuasan karyawan dapat ditunjukkan dengan berbagai cara, seperti melakukan protes, malas bekerja, tidak patuh, hingga berhenti bekerja.

Menurut Luthans (2009), kepuasan kerja karyawan adalah perasaan positif yang terbentuk dari penilaian karyawan terhadap pekerjaannya berdasarkan persepsi karyawan mengenai seberapa baik pekerjaannya, yang berarti bahwa apa yang diperoleh dalam bekerja sudah memenuhi apa yang dianggap penting. Menurut Edy Sutrisno (2014), kepuasan keja menjadi masalah yang cukup menarik dan penting, karena terbukti besar manfaatnya bagi kepentingan individu, industri dan masyarakat.

Kemudian menurut Abdul Wahab (2012), Kepuasan kerja (job satisfaction) adalah keadaan emosional yang menyenangkan atau tidak menyenangkan bagaimana para karyawan memandang pekerjaan mereka. Kepuasan kerja menggambarkan perasaan seseorang terhadap hasil kerjanya. Kepuasan kerja menurut Dadang (2013) adalah keadaan emosional yang menyenangkan atau tidak menyenangkan terhadap pekerjaan, kepuasan kerja mencerminkan perasaan seeorang terhadap terhadap pekerjaannya. Menurut (Sandika \& Andani, 2020) para pegawai di masing masing bagian pekerjaannya merasa bahwa dimensi-dimensi kepuasan kerja tersebut apabila dapat terpenuhi serta didukung secara maksimal oleh perusahaan sesuai dengan harapan pegawai, maka akan meningkatkan kinerja mereka dalam melaksanakan pekerjaannya

\section{Kinerja Karyawan}

Pada dasarnya kinerja seorang karyawan merupakan hal yang bersifat pribadi karena setiap karyawan memiliki tingkat kemampuan dan keterampilan pada bidang yang berbeda dalam melaksanakan tugas yang diberikan. Umumnya kinerja yang bagus adalah kinerja yang mengikuti tata cara atau sesuai dengan standar yang telah ditetapkan. Untuk memudahkan penilaian kinerja karyawan, standar pekerjaan harus dapat diukur dan dapat dipahami secara jelas.

Marwansyah (2016) mendefinisikan kinerja sebagai pencapaian atau prestasi sesorang bekenaan dengan tugas-tugas yang dibebankan kepadanya. Sedangkan menurut Sedarmayanti (2015), kinerja merupakan terjemahan dari performance yang berarti hasil kerja seorang pekerja, sebuah proses manajemen atau suatu organisasi secara keseluruhan, dimana hasil kerja tersebut harus dapat ditunjukkan buktinya secara konkrit dan dapat diukur (dibandingkan dengan standar yang telah ditentukan).

Torang (2014) mendefinsikan kinerja karyawan sebagai suatu kuantitas dan atau kualitas hasil kerja individu atau kelompok di dalam organisasi dalam melaksanakan tugas pokok dan fungsi yang berpedoman pada norma, standar operasional prosedur, kriteria dan ukuran yang telah ditetapkan atau yang berlaku dalam organisasi. Menurut valentine Kinerja adalah hasil kerja yang dapat dicapai oleh seseorang atau kelompok orang dalam suatu perusahaan sesuai dengan wewenang dan tanggung jawab masing-masing dalam upaya pencapaian tujuan perusahaan. Dari uraian di atas maka dapat diambil kesimpulan bahwa kinerja adalah hasil 
kerja yang dihasilkan oleh seorang karyawan untuk mencapai target dan tujuan perusahaan atau organisasi secara kuantitas maupun kualitas.

Kerangka pemikiran dalam penelitian ini sebagai berikut:

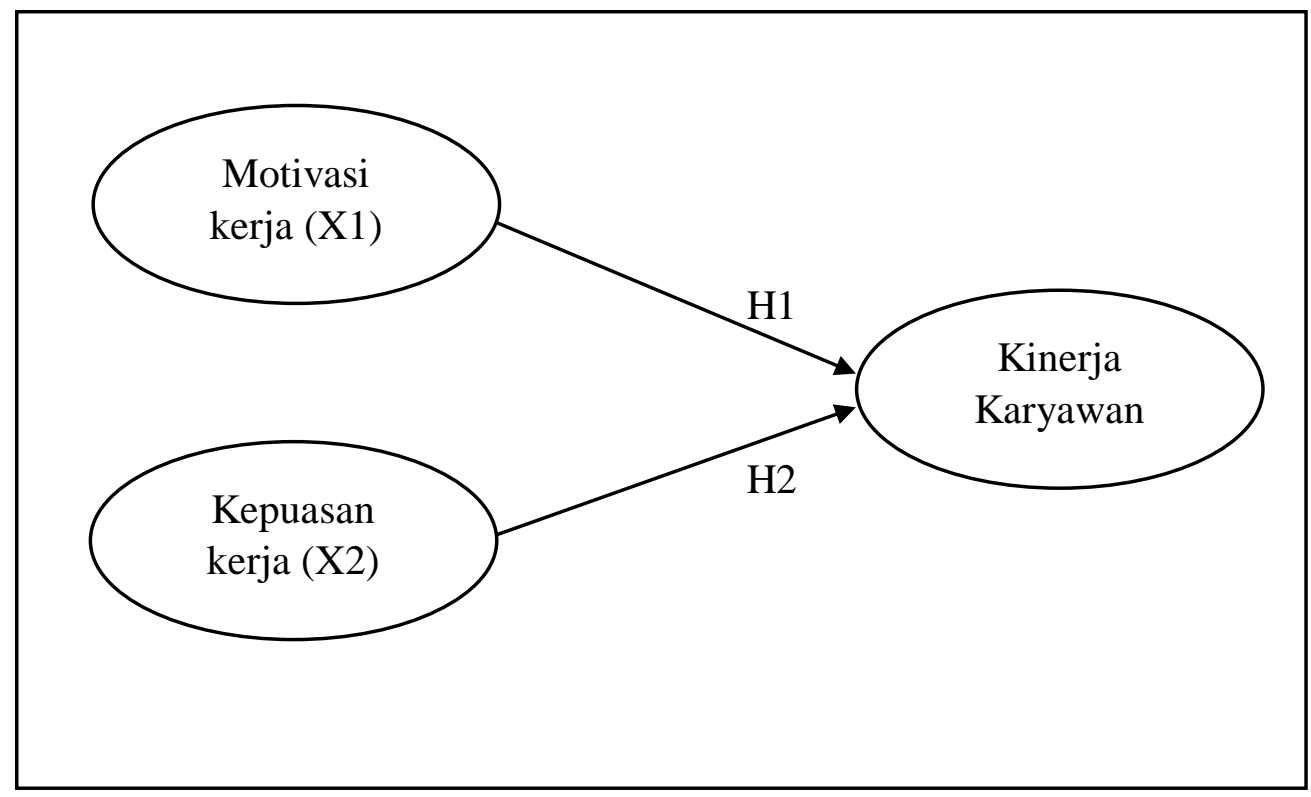

Gambar 1.

Kerangka Pemikiran

\section{Hipotesis Penelitian:}

Berdasarkan kerangka pemikiran diatas, maka hipotesis pada penelitian ini dirumuskan sebagai berikut:

$\mathrm{H}_{1}$ : Motivasi kerja memiliki pengaruh yang positif terhadap kinerja karyawan pada PT. Togo Steel Industries di Tangerang.

$\mathrm{H}_{2}$ : Kepuasan kerja memiliki pengaruh yang positif terhadap kinerja karyawan pada PT. Togo Steel Industries di Tangerang.

\section{METODOLOGI}

Variabel terikat dalam penelitian ini adalah kinerja karyawan sedangkan variabel bebas nya adalah motivasi kerja dan kepuasan kerja. Metode pengambilan sampel yang digunakan dalam penelitian ini adalah teknik pemilihan sampel jenuh. Sampel yang digunakan dalam penelitian ini adalah setiap anggota populasi penelitian ini, yaitu seluruh karyawan PT. Togo Steel Industries di Tangerang dengan jumlah 85 orang karyawan. Teknik pengumpulan data dalam penelitian ini menggunakan kuesioner dan kemudian data dari responden akan dikelola melalu aplikasi SmartPLS 3.3.3. Uji statistik yang digunakan dalam SmartPLS versi 3.3.3 adalah sebagai berikut:

Uji validitas dilakukan dengan mengukur nilai discriminant validity dan convergent validity. Nilai convergent validity dikatakan valid apabila nilai Average Variance Extracted $(A V E)$ di atas 0,5 $(A V E>0,5)$, dan nilai loading factor pada masing-masing variabel di atas 0,7 (loading factor $>0,7$ ). Lalu discriminant validity dapat diukur dengan tabel cross loading 
dengan cara membandingkan korelasi indikator suatu konstruk tersebut dengan konstruk lainnya. Jika korelasi indikator terhadap variabelnya memiliki nilai lebih besar dibandingkan dengan korelasi indikator tersebut terhadap variabel lain, maka dikatakan konstruk memiliki validitas diskriminan yang tinggi.

Uji reliabilitas dilakukan menggunakan metode Cronbach Alpha $(\alpha)$. Variabel dikatakan reliabel apabila nilai Cronbach Alpha $(\alpha)$ lebih besar atau sama dengan $0,6(\alpha \geq 0,6)$. Nilai reliabilitas indikator-indikator pada suatu konstruk juga dapat diuji menggunakan pendekatan Composite Reliability. Apabila suatu konstruk atau variabel memiliki nilai composite reliability diatas 0,7 (> 0.7) maka dapat dikatakan bahwa konstruk atau variabel tersebut memenuhi Composite Reliability. Selanjutnya, untuk hasil analisis data dapat dilakukan pengujian sebagai berikut:

1. Koefisien Determinasi $\left(\mathrm{R}^{2}\right)$

Uji koefisien determinasi bertujuan untuk mengukur seberapa jauh kemampuan model dalam menerangkan variasi variabel dependen.

2. Uji Goodness Of Fit (GoF)

Uji Goodness of Fit atau uji kelayakan model dilakukan untuk mengukur ketepatan fungsi regresi sampel dalam menaksir nilai aktual. Nilai Goodness of Fit berada di rentang angka 0 (nol) sampai 1 (satu) dengan interpretasi yaitu pada angka 0,1 nilai $G o F$ dikatakan kecil, 0,25 nilai $G o F$ dikatakan moderat, dan nilai $G o F$ dikatakan besar bila memiliki nilai 0,36 atau lebih.

3. Uji Hipotesis

Untuk mengetahui apakah suatu hipotesis dapat diterima atau ditolak dapat dialkukan dengan menghitung nilai signifikansi antar konstrak, t-statistik, dan pvalues yang dapat ditinjau pada hasil bootstrapping dalam software SmartPLS (Partial Least Square).

\section{HASIL UJI STATISTIK}

Deskripsi Subjek Penelitian 
Jenis Kelamin

85 responses

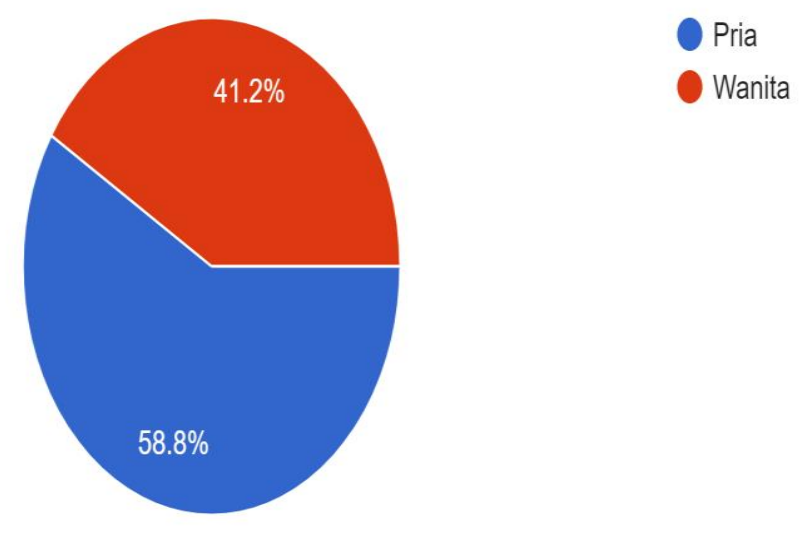

Gambar 2.

Data Jenis Kelamin Responden

Usia

85 responses

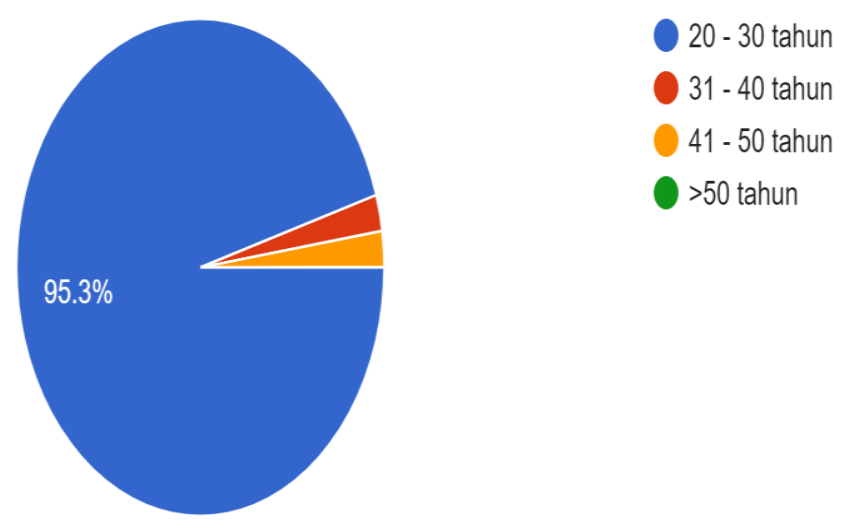

Gambar 3.

Data Usia Responden

Uji Validitas

Tabel 1.

Hasil Uji Validitas 


\begin{tabular}{|c|c|}
\hline Variabel & Rata-rata Varians Diekstrak $(\boldsymbol{A} \boldsymbol{V E})$ \\
\hline Motivasi Kerja & 0.600 \\
\hline Kepuasan Kerja & 0.578 \\
\hline Kinerja Karyawan & 0.544 \\
\hline
\end{tabular}

Sumber : Hasil pengelolahan data melalui SmartPLS 3.3.3

Nilai AVE dari setiap variabel lebih besar dari 0,5, sehingga dapat disimpulkan bahwa variabel - variabel diatas dapat dikatakan telah memenuhi persyaratan analisis validitas konvergen.

\section{Uji Reabilitas}

Tabel 2.

Hasil Analisis Reliabilitas

\begin{tabular}{|l|c|c|}
\hline \multicolumn{1}{|c|}{ Variabel } & Cronbach's Alpha & Composite Reliability \\
\hline Motivasi Kerja & 0.834 & 0.882 \\
\hline Kepuasan Kerja & 0.757 & 0.845 \\
\hline Kinerja Karyawan & 0.791 & 0.856 \\
\hline
\end{tabular}

Sumber : Hasil pengelolahan data melalui SmartPLS 3.3.3

Seluruh konstruk atau variabel memiliki nilai Cronbach Alpha dan Composite Reliability yang lebih besar dari $0,7(<0,7)$ maka dapat dikatakan bahwa konstruk atau variabel tersebut memenuhi syarat.

Tabel 3.

Hasil Uji Koefisien Determinan(Uji R)

\begin{tabular}{|c|c|}
\hline Variabel & $\boldsymbol{R}$-Square \\
\hline Kinerja Karyawan & 0,663 \\
\hline
\end{tabular}

Sumber : Hasil pengelolahan data melalui SmartPLS 3.3.3

Berdasarkan hasil pengujian diatas, dapat diketahui bahwa Motivasi Kerja dan Kepuasan Kerja mampu menjelaskan variabel Kinerja Karyawan sebesar 66,3\%.

Tabel 4.

Hasil Uji Normed Fit Index (NFI)

\begin{tabular}{|c|c|}
\hline & Saturated Model \\
\hline NFI & 0.681 \\
\hline
\end{tabular}

Sumber : Hasil pengelolahan data melalui SmartPLS 3.3.3

Berdasarkan hasil pengujian Normed Fit Index (NFI) pada tabel diatas maka dapat disimpulkan bahwa nilai $G o F$ pada penelitian ini memiliki nilai yang besar, yaitu sebesar 
$0,681(G o F>0,36)$ yang berarti bahwa model yang digunakan dalam penelitian ini sesuai atau tepat.

Tabel 5. Uji Hipotesis

\begin{tabular}{|l|l|c|c|}
\hline Hipotesis & \multicolumn{1}{|c|}{ Variabel } & t-statistics & p-values \\
\hline H1 & Motivasi Kerja $\rightarrow$ Kinerja Karyawan & 2.412 & 0.016 \\
\hline H2 & Kepuasan Kerja $\rightarrow$ Kinerja Karyawan & 5.636 & 0.000 \\
\hline
\end{tabular}

Sumber : Hasil pengelolahan data melalui SmartPLS 3.3.3

Berdasarkan hasil uji bootstrapping diatas, variabel Motivasi Kerja terbukti berpengaruh secara positif terhadap Kinerja Karyawan pada PT. Togo Steel Industries di Tangerang. Hasil tersebut dapat dilihat berdasarkan nilai t-statistics dari Motivasi Kerja terhadap Kinerja Karyawan dengan nilai sebesar 2,412 yang lebih besar dari t-tabel yaitu 1,96, dan juga nilai $p$-values sebesar 0,016 yang lebih kecil dari $\alpha=0,05$.

Variabel Kepuasan Kerja terbukti berpengaruh secara positif terhadap Kinerja Karyawan pada PT. Togo Steel Industries di Tangerang. Hasil tersebut dapat dilihat berdasarkan nilai $t$ statistics dari Kepuasan Kerja terhadap Kinerja Karyawan dengan nilai sebesar 5,636 yang lebih besar dari t-tabel yaitu 1,96, dan juga nilai $p$-values sebesar 0,000 yang lebih kecil dari $\alpha=0,05$.

\section{DISKUSI}

Berdasarkan hasil hipotesis pertama penelitian ini dapat diketahui bahwa motivasi kerja memiliki pengaruh positif terhadap kinerja karyawan. Hasil ini dapat dilihat pada hasil pengujian boothstrapping Hal ini menujukkan bahwa semakin tinggi tingkat motivasi kerja yang dimiliki karyawan, maka akan semakin tinggi juga tingkat kinerja karyawan.

Kemudian berdasarkan hasil hipotesis kedua penelitian ini menjelaskan bahwa kepuasan kerja memiliki pengaruh positif terhadap kinerja karyawan. Hal ini menujukkan bahwa semakin tinggi tingkat kepuasan kerja yang dimiliki karyawan, maka akan semakin tinggi juga tingkat kinerja karyawan.

Berdasarkan hasil hipotesis penelitian ini dapat diketahui bahwa motivasi kerja dan kepuasan kerja memiliki pengaruh positif terhadap kinerja karyawan. Hasil penelitian ini didukung oleh penelitian yang dilakukan Florida Dessy Putri Sanuddin dan A.M. Rosa Widjojo (2013) dalam penelitian yang berjudul "Pengaruh Kepuasan Kerja dan Motivasi Kerja Terhadap Kinerja Karyawan PT. Semen Tonasa" yang menunjukan bahwa kepuasan kerja dan motivasi kerja secara simultan berpengaruh terhadap kinerja karyawan PT. Semen Tonasa.

\section{PENUTUP}

Berdasarkan hasil analisis data dan uji hipotesis dalam penelitian ini, dapat disimpulkan bahwa (1) Motivasi kerja memiliki pengaruh yang positif terhadap kinerja karyawan pada PT. Togo Steel Industries di Tangerang, (2) Kepuasan kerja memiliki pengaruh yang positif terhadap kinerja karyawan pada PT. Togo Steel Industries di Tangerang.

Berdasarkan dari hasil penelitian yang telah dilakukan, terdapat beberapa saran atau masukan yang sekiranya dapat digunakan atau bermanfaat bagi perusahaan maupun kepada penelitian selanjutnya, sebagai berikut:

a) Bagi Perusahaan 
Diharapkan perusahaan dapat membuat kebijakan kepuasan kerja menjadi lebih prioritas karena memiliki pengaruh yang lebih besar dari variabel motivasi kerja, terutama pada indikator kenyamanan saat bekerja. Kemudian perusahaan diharapkan juga untuk membuat prioritas kebijkan yang efektif pada kinerja karyawan terutama pada indikator kerapihan karena merupakan indikator yang paling besar dipengaruhi oleh motivasi kerja dan kepuasan kerja.

b) Bagi Peneliti Selanjutnya

Diharapkan peneliti selanjutnya dapat memperbanyak jumlah variabel untuk penelitian yang serupa karena pada uji koefisien determinasi $\left(\mathrm{R}^{2}\right)$ menunjukkan bahwa masih ada variabel - variabel yang memiliki pengaruh terhadap kinerja karyawan. Diharapkan juga untuk peniliti selanjutnya dapat memperluas jangkauan pemberian sampel dari pada penelitian sebelumnya sehingga mampu memberikan hasil penelitian yang bervariasi, baik itu memperkuat hasil penelitian sebelumnya maupun sebaliknya.

\section{DAFTAR PUSTAKA}

Abdul Wahab, S. (2012). ANALISIS KEBIJAKAN: Dari Formulasi ke penyusunan ModelModel Implementasi Kebijakan Publik. Jakarta: PT. Bumi Aksara.

Anoraga, P. (2014). Psikologi Kerja. Jakarta: Rineka Cipta.

Bangun, W. (2012). Manajemen Sumber Daya Manusia. Jakarta: Erlangga.

Dadang. (2013). E-Business \& E-Commerce. Yogyakarta: Andi.

Dessy Putri Sanuddin, F., \& Rosa Widjojo, A. (2013). PENGARUH KEPUASAN KERJA DAN MOTIVASI KERJA TERHADAP KINERJA KARYAWAN PT. SEMEN TONASA. MODUS, 25, 217-231.

Edy Sutrisno. (2014). Manajemen Sumber Daya Manusia (6 ed.). Jakarta: Pranada Media Group.

Hariandja, M. E. (2002). Manajemen Sumber Daya Manusia. Jakarta: Grasindo.

Luthans, F. (2009). Perilaku Organisasi. Yogyakarta: Andy Offset.

Marwansyah. (2016). Manajemen Sumber Daya Manusia (2 ed., Vol. 4). Bandung: Alfabeta.

Reksohadiprodjo, S., \& Handoko, T. H. (2001). Manajemen Sumber Daya Manusia dan Perusahaan. Yogyakarta: BPEE.

Sandika, \& Andani, K. W. (2020). Pengaruh Motivasi, Kepuasan Kerja, Dan Disiplin Kerja Terhadap Kinerja Karyawan. Jurnal Manajerial dan Kewirausahaan, 162-172.

Saputra, S., \& Andani, K. W. (2021). FAKTOR-FAKTOR YANG MEMPENGARUHI KEPUASAN KERJA KARYAWAN PADA PT CITRA CROCOTAMA INTERNATIONAL DI JAKARTA. Jurnal Manajerial dan Kewirausahaan, 98-106.

Sedarmayanti. (2015). Manajemen Sumber Daya Manusia. Bandung: Refika Aditama.

Torang, D. S. (2014). Organisasi dan Manajemen. Bandung: Alfabeta.

Torang, D. S. (2016). Organisasi Dan Manajemen (Perilaku, Struktur, Budaya dan Perubahan Organisasi). Bandung: Alfabeta. 